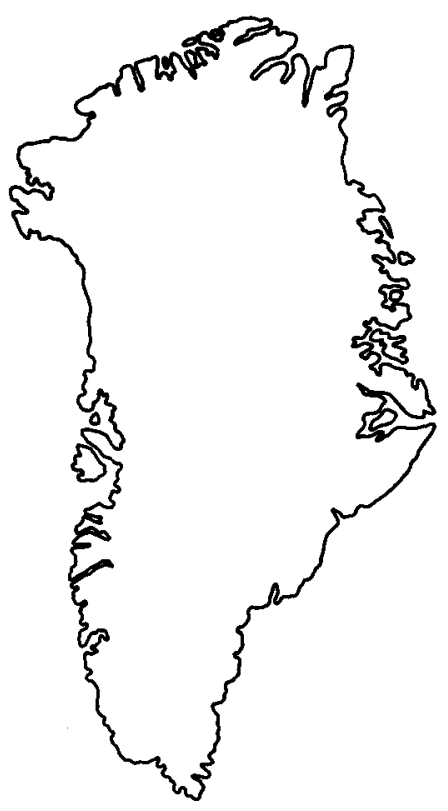

\title{
An upper Llandovery conodont fauna from Peary Land, eastern North Greenland
}

\author{
R.J. Aldridge
}

\begin{abstract}
A limestone sample from near the top of the Silurian carbonate sequence in Peary Land, eastern North Greenland has yielded a diverse conodont fauna referable to the celloni Zone. By comparison with faunas from Britain, a Telychian age is indicated. One new species, Ozarkodina broenlundi, is recognised and a new multi-element reconstruction of Oulodus? fluegeli (Walliser) is suggested.
\end{abstract}

R. J. A. Department of Geology, University of Nottingham, University Park, Nottingham NG7 2RD, U.K.

Strata of Proterozoic and lower Palaeozoic age are exposed over wide areas in North Greenland. Two broad east-west belts are differentiated, a southern belt of carbonates and relatively thin clastic sediments deposited on a stable platform and a northern geosynclinal region characterised by thick, folded sequences of clastic sediments and argillaceous limestones (Dawes, 1976). The eastern limit of the undeformed platform sequence is in south Peary Land, where the area around Jørgen Brønlund Fjord has received most attention from expeditions. A history of geological field work in this area was given by Jepsen (1971), and a summary of current knowledge by Dawes (1976). In 1974, officers of the Geological Survey of Greenland made substantial palaeontological and lithological collections in the valley of Børglum Elv, flowing south into Jørgen Brønlund Fjord, in order to establish a reference profile through the lower Palaeozoic succession (Peel \& Christie, 1975; Christie \& Peel, 1977). Here, a succession of Cambrian and Ordovician formations is conformably overlain by about $1500 \mathrm{~m}$ of Silurian sediments, which have been divided into the following units:

$\begin{array}{ll}\text { Un-named Silurian flysch formation } & 800 \mathrm{~m}+ \\ \text { Un-named Silurian black shale formation } & 100 \mathrm{~m} \\ \text { Un-named Silurian limestone formation } & 320 \mathrm{~m} \\ \text { Un-named Silurian (?) dolomite formation } & 150 \mathrm{~m}\end{array}$

As part of the palaeontological investigation, a single sample (GGU 184125) from the upper part of the Silurian limestone unit was examined for conodonts. The sample yielded a diverse conodont collection, allowing this part of the sequence to be dated, and gives a preliminary indication of the potential of conodonts as biostratigraphic tools in the Silurian of North Greenland. 


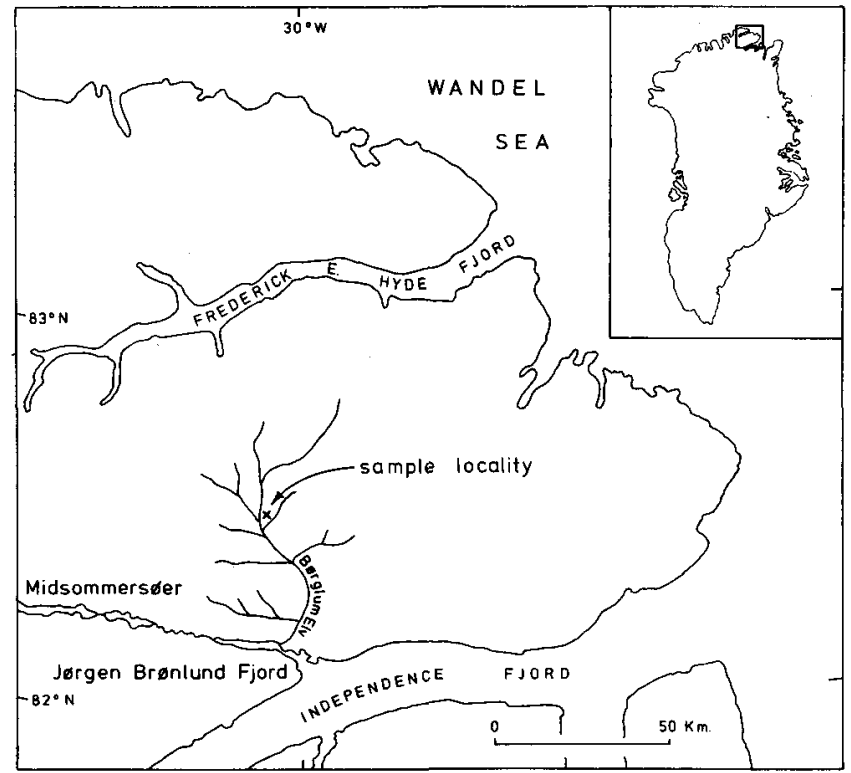

Fig. 1. Outline map of Peary Land, eastern North Greenland, showing sample locality.

GGU sample 184125 is from thinly-bedded, dark grey limestones of member F of the Unnamed Silurian limestone formation (Christie \& Peel, 1977, p. 27), a few metres below the top of the Silurian carbonate sequence. The sample locality is a fault gully east of the confluence of Børglum Elv with the main (un-named) tributary from the north-west (fig. 1). Peel \& Christie (1975, p. 24) and Christie \& Peel (1977, p. 27) recorded scutelluid, phacopid and encrinurid trilobites, the gastropods Liospira and Loxonema, brachiopods (dominated by Strophonella), and Favosites from Member F. The overlying Silurian shale has yielded monograptids and a cyrtograptid, indicative of a late Wenlock age (M. Bjerreskov, pers. comm. to J.S. Peel, 1975).

\section{The conodont fauna}

The conodont collection recovered by acetic acid digestion of $5 \mathrm{~kg}$ of limestone comprises more than 600 identifiable elements, together with a number of fragmentary specimens. Many of the specimens are well-preserved, although their black colouration masks the distribution of white matter. As the sample is isolated and relatively small, it is not possible to assign all the elements with certainty to multi-element taxa, but relationships between most of the forms may be suggested. Uncertain assignments are indicated in the faunal list given below.

$\begin{array}{lll}\text { Aulacognathus bullatus (Nicoll \& Rexroad) } & \text { Pa element } & 4 \\ \text { Aulacognathus latus } \text { (Nicoll \& Rexroad) } & \text { Pa element } & 1 \\ \text { Aulacognathus sp. } & \text { Pb element } & 4 \\ \text { Carniodus carnulus Walliser } & \text { Sc? element } & 3 \\ \text { Carniodus sp. } & \text { M? element } & 9 \\ \text { Dapsilodus sp. } & & 1 \\ \text { Decoriconus } s p . & & 1\end{array}$




\begin{tabular}{|c|c|c|}
\hline \multirow[t]{4}{*}{ Distomodus staurognathoides (Walliser) } & \multicolumn{2}{|l|}{ Pa element } \\
\hline & M element & 2 \\
\hline & Sb element & 3 \\
\hline & Sc element & 3 \\
\hline Llandoverygnathus celloni (Walliser) & $\mathrm{Pa}$ element & 20 \\
\hline Llandoverygnathus pennatus (Walliser) & $\mathrm{Pa}$ element & 3 \\
\hline \multirow[t]{5}{*}{ Llandoverygnathus sp. } & $\mathrm{Pb}$ element & 16 \\
\hline & M element & 6 \\
\hline & Sc element & 8 \\
\hline & Sa element? & 3 \\
\hline & Sb element? & 4 \\
\hline Oulodus sp. B. Cooper, 1975 & M element & 1 \\
\hline \multirow[t]{4}{*}{ Oulodus sp. A. } & M element & 5 \\
\hline & Sa element & 3 \\
\hline & Sb element & 5 \\
\hline & Sc element & 5 \\
\hline \multirow[t]{6}{*}{ Oulodus? fluegeli (Walliser) } & $\mathrm{Pa}$ element & 5 \\
\hline & $\mathrm{Pb}$ element & 4 \\
\hline & M element & $28 ?$ \\
\hline & Sa element & 6 \\
\hline & Sb element & 8 \\
\hline & Sc element & $11 ?$ \\
\hline \multirow[t]{6}{*}{ Ozarkodina broenlundi sp. nov. } & $\mathrm{Pa}$ element & 40 \\
\hline & $\mathrm{Pb}$ element & 19 \\
\hline & M element & 7 \\
\hline & Sa element & 3 \\
\hline & Sb element & 10 \\
\hline & Sc element & 18 \\
\hline \multirow{6}{*}{$\begin{array}{l}\text { Ozarkodina aff. } O \text {. polinclinata } \\
\text { (Nicoll \& Rexroad) }\end{array}$} & $\mathrm{Pa}$ element & 14 \\
\hline & $\mathrm{Pb}$ element & 3 \\
\hline & M element & $7 ?$ \\
\hline & Sa element & 3 \\
\hline & Sb element & 6 \\
\hline & Sc element? & 4 \\
\hline Ozarkodina sp. & $\mathrm{Pb}$ element & 1 \\
\hline Panderodus unicostatus (Branson \& Mehl) & all elements & 269 \\
\hline Panderodus spp. & & 81 \\
\hline
\end{tabular}

The abbreviations used above to designate the constituent elements of multi-element apparatuses are those proposed by Sweet \& Schönlaub (1975) in their paper on Oulodus. This scheme was devised as an alternative to those suggested previously by Jeppsson (1971) and Klapper \& Philip (1971), and is to be adopted in the revised part W of the Treatise on Invertebrate Paleontology (Barrick \& Klapper, 1976, p. 68). The application of the scheme to Ozarkodina and other genera with comparable apparatuses is in accordance with the usage by Cooper (1975).

\section{Correlation}

The base of the celloni Zone of Walliser (1964) is defined at the first appearance of Llandoverygnathus celloni and the top at the first appearance of Pterospathodus amorphognathoides 
Walliser. L. celloni has not been recorded from the amorphognathoides Zone, so its presence in the sample GGU 184125 allows a confident assignment to the celloni Zone. Elements of Carniodus carnulus, Distomodus staurognathoides, Llandoverygnathus pennatus and Oulodus? fluegeli were considered by Walliser $(1964$, pls 5,6$)$ to be characteristic of both the celloni and amorphognathoides Zones. The celloni Zone is approximately equivalent to the Icriodella inconstans Zone defined in Britain (Aldridge, 1972). The upper limits are certainly coincident, both being defined at the first appearance of $P$. amorphognathoides, which in Britain occurs just below the Llandovery/Wenlock boundary (Aldridge, 1975, p. 613). The known stratigraphic range of $L$. celloni in Britain is wholly within the Telychian Stage of the upper Llandovery (Aldridge, 1975, fig. 1), so a Telychian age for the sample GGU 184125 is indicated. The ranges of other taxa common to Britain and Greenland are consistent with this assignment.

\section{Systematic palaeontology}

The transition in conodont taxonomy from a single element to a multi-element basis has provided the possibility of producing a meaningful supra-generic classification. There have been some creditable early attempts in this direction (Lindström, 1970; Klapper \& Philip, 1972; Klapper \& Murphy, 1975; Cooper, 1977), but there are many points of controversy and many genera remain unclassified. At present, it appears advisable to adhere to the standard approach of treating genera in alphabetical order.

Where no new discussion is merited, well-known taxa are omitted from the systematic section. All species included in this section and several elements of other species are illustrated. Figured specimens are deposited in the type collection of the Geologisk Museum, Copenhagen, and the remainder of the collection is kept for reference at the Geological Survey of Greenland in Copenhagen.

\section{Genus Aulacognathus Mostler, 1967}

1967 Aulacognathus Mostler, p. 300.

1969 Neospathognathodus Nicoll \& Rexroad, pp. 42-44.

Type species. By original designation, Aulacognathus kuehni Mostler, 1967, p. 300; from the Llandovery of Westendorf, Kitzbühl Alps, Austria.

Emended diagnosis. Platform $(\mathrm{Pa})$ element with nodose inner and outer lateral processes. Inner process consisting of a single lobe, directed inwards and anteriorly; outer process with one to three lobes. Posterior end of carina commonly bent inwards and sometimes thickened laterally. Anterior blade free. Arched blade $(\mathrm{Pb})$ element typically with a well-developed apical denticle near the posterior end. Short inner and outer lateral processes beneath the apical denticle may each bear a median row of nodes.

Remarks. Klapper \& Murphy (1975, p. 25) placed Aulacognathus and Neospathognathodus in synonymy on the basis of similarities in the platform elements. This proposal is strengthened by the close resemblance between the $\mathrm{Pb}$ elements of the three species now referred to Aulacognathus: $A$. bullatus, $A$. kuehni and $A$. latus. This similarity is so marked that the single form-species Neospathognathodus ceratoides Nicoll \& Rexroad appears previously to have accommodated the arched blade elements of all three apparatuses. $N$. ceratoides was recorded in association 
with platform elements of $A$. bullatus and $A$. latus by Nicoll \& Rexroad (1969, table 1) and, as Aulacognathus ceratoides, by Klapper \& Murphy (1975, table 1). A consistent association of $N$. ceratoides with A. kuehni, the type species of Aulacognathus, is also evident in material from Britain (Aldridge, 1975, p. 609, pl. 3, figs 13, 20, 21).

\title{
Aulacognathus bullatus (Nicoll \& Rexroad, 1969)
}

\author{
Plate 1, figs 1, 6, 7 . \\ v 1964 Spathognathodus sp., ex aff. Sp. celloni Walliser; Walliser, p. 74, pl. 14, figs 17, 18. \\ v* 1969 Neospathognathodus bullatus Nicoll \& Rexroad, pp. 44-45, pl. 1, figs 5-7. \\ v 1970 Neospathognathodus bullatus Nicoll \& Rexroad; Rexroad \& Nicoll, pl. 1, fig. 7. \\ v 1972 Neospathognathodus bullatus Nicoll \& Rexroad; Aldridge, p. 196, pl. 3, fig. 15. \\ ?p 1975 Aulacognathus ceratoides (Nicoll \& Rexroad); Klapper \& Murphy, p. 26, pl. 1, figs 4, 5, 8-12 \\ (non figs. 13, 14). \\ 1975 Neospathognathodus bullatus Nicoll \& Rexroad; Schönlaub, p. 59, pl. 1, fig. 6.
}

Remarks. Although there are relatively few records of the platform $(\mathrm{Pa})$ element, a wide range of morphology has been illustrated and a partial ontogenetic series was figured by Klapper \& Murphy (1975). Only the collections of Nicoll \& Rexroad (1969) with 25 specimens and of Klapper \& Murphy (1975) with 39 specimens contain more than a few examples, and it is in their material that one might expect to recognise the associated $\mathrm{Pb}$ elements. $\mathrm{Pb}$ elements, assigned to $N$. ceratoides, do occur in most of the samples with $A$. bullatus platforms recorded by Nicoll \& Rexroad (1969, table 1), but in all cases the Pa element of $A$. latus is also present. The $\mathrm{Pb}$ elements illustrated by Nicoll \& Rexroad (1969, p. 1, figs 1-4) could, therefore, be from either $A$. bullatus or $A$. latus apparatuses. As a total of 295 specimens of the Pa element of $A$. latus were recovered by Nicoll \& Rexroad (1969, p. 47), the Pb specimens chosen for illustration are, perhaps, more likely to have come from the $A$. latus apparatus. Cooper (1977) appears to have accepted this probability in his assignment of two arched blades from Nicoll \& Rexroad's collections to the A. latus apparatus (Cooper 1977, p. 1063, pl. 2, figs 1, 5). The possibility that these specimens were from the $A$. bullatus apparatus was not considered, and in the absence of any new evidence the assignment of these $\mathrm{Pb}$ elements must be questionable.

In the material described by Klapper \& Murphy (1975), forms referred to A. bullatus, $A$. kuehni and $A$. ceratoides are associated and the $\mathrm{Pb}$ elements may be from either the $A$. bullatus or the A. kuehni apparatus. Klapper \& Murphy (1975, pl. 1, figs 4, 5, 8-14) figured five specimens of the $\mathrm{Pb}$ element of Aulacognathus, three of which (figs 4, 5, 8-10) are from sample BC I 2.1-2.5 $\mathrm{ft}$.. In this sample, 27 arched blades are associated with 37 platforms of $A$. bullatus and 6 of $A$. kuehni, which suggests that the figured specimens may be from the $A$. bullatus apparatus. The specimen shown in figs. 11-12 occurs, in sample BC I $4.0 \mathrm{ft}$., with one specimen each of the platform of $A$. bullatus and $A$. kuehni and is not necessarily related to either. The specimen in figs. 13-14 is the only Aulacognathus $\mathrm{Pb}$ element from sample BC I 6.1-7.8 ft., with a single platform of $A$. latus being the only $\mathrm{Pa}$ element. There is no reason to suspect that this $\mathrm{Pb}$ element may belong to $A$. bullatus.

The resolution of the problem of $\mathrm{Pb}$ element assignment awaits the detailed examination of unambiguous samples. Meanwhile, in samples containing more than one Aulacognathus species, such as that described here, the specific assignment of the arched blade elements must remain in doubt. 


\section{Aulacognathus latus (Nicoll \& Rexroad, 1969)}

Plate 1, figs 4,5 .

$\mathrm{v}^{*} 1969$ Neospathognathodus latus Nicoll \& Rexroad, pp. 46-47, pl. 1, figs 8-11.

v? 1969 Neospathognathodus ceratoides Nicoll \& Rexroad, p. 46, pl. 1, figs 1-4.

1972 Neospathognathodus latus Nicoll \& Rexroad; Rexroad \& Nicoll, pl. 2, fig. 41.

1975 Aulacognathus latus (Nicoll \& Rexroad); Klapper \& Murphy, p. 26, pl. 1, figs 6, 7.

1977 Aulacognathus latus (Nicoll \& Rexroad); Cooper, p. 1063, pl. 2, figs 2, 10.

? 1977 Aulacognathus latus (Nicoll \& Rexroad). Cooper, p. 1063, pl. 2, figs 1, 5.

Remarks. A single, almost complete specimen and a few fragments exhibit the low, broad platforms characteristic of the $\mathrm{Pa}$ element of $A$. latus. The problem of allocating specimens $\mathrm{Pb}$ elements to the $A$. latus apparatus is discussed under $A$. bullatus.

\section{Aulacognathus sp.}

Plate 1, figs 2, 3.

Remarks. Four examples of the $\mathrm{Pb}$ element of Aulacognathus are present in the Greenland collection. The lateral processes on these specimens are very short; on two specimens they are unornamented and on the other two they bear a single node each. In this respect they resemble more closely some of the specimens figured by Klapper \& Murphy (1975) than those figured by Nicoll \& Rexroad (1969) and Cooper (1977), and it is possible that they represent the $\mathrm{Pb}$ element of $A$. bullatus. However, as discussed under $A$. bullatus, it is impossible to be certain of this assignment and some, or all, of the specimens may have come from the $A$. latus apparatus.

\section{Genus Carniodus, Walliser, 1964}

Type species. By original designation, Carniodus carnulus Walliser, 1964, p. 30; from the Silurian Trilobiten und Aulacopleura Schichten of Mount Cellon, Carnic Alps, Austria.

\section{Carniodus sp.}

Plate 1, fig. 8

Remarks. The morphology of the cusp and basal cavity of these nine specimens closely resembles that of Carniodus carnicus Walliser (1964, p. 32, pl. 28, figs 8-11), but the denticulated lateral processes of that form are lacking. Barrick \& Klapper (1976, pp. 68-69) have suggested that C. carnicus is the $\mathrm{M}$ element in the apparatus of Carniodus carnulus, and it is possible that these simpler specimens represent the $\mathrm{M}$ element of a similar apparatus.

\section{Genus Oulodus Branson \& Mehl, 1933}

1933b Oulodus Branson \& Mehl, p. 116.

1935a Gyrognathus Stauffer, p. 144.

1935b Barbarodina Stauffer, pp. 602-603.

1969 Ligonodina Bassler; Jeppsson, pp. 20-21.

1971 Delotaxis Klapper \& Philip, p. 446. 
Type species. Cordylodus serratus Stauffer, 1930, p. 124; from the Ordovician Decorah Shale of Minnesota. Senior subjective synonym of Oulodus mediocris Branson \& Mehl, 1933b, p. 116, the originally designated type species; by subsequent designation of Sweet \& Schönlaub, 1975, p. 45.

\title{
Oulodus sp. B Cooper, 1975
}

\author{
Plate 2, fig. 12.
}

1967 Neoprioniodus planus Walliser; Rexroad, p. 39, pl. 3, fig. 11.

p 1970 Neoprioniodus cf. N. excavatus (Branson \& Mehl); Pollock, Rexroad \& Nicoll, p. 756, pl. 114, fig. 20 (only).

1975 Oulodus sp. B Cooper, pp. 997-998, pl. 2, figs 15, 17, 20, 22 (see further synonymy).

Description. This species is represented by a single specimen of the neoprioniodontiform $M$ element. The unit comprises a curved cusp and a single process, posterior to the cusp. Cusp prominent, elliptical in transverse section with a sharp and straight anterior margin; no anterior or antero-lateral process. Posterior process slightly curved downwards, bearing four discrete denticles, subequal in size and separated by broad U-spaces. Basal cavity widely flared immediately posterior to the cusp and tapering to a point beneath the anterior and posterior tips of the unit.

\section{Oulodus sp. A}

Plate 2, figs 13-16.

Description. Four elements are believed to represent the $\mathrm{M}, \mathrm{Sa}, \mathrm{Sb}$ and $\mathrm{Sc}$ components of a single species of Oulodus.

M element - neoprioniodontiform, with a recurved cusp and processes that are lateral and antero-lateral to the cusp. Cusp elliptical to sub-circular in transverse section, inclined away from the longer, lateral process. Antero-lateral process of four specimens very short, with a single denticle; fifth specimen broken. Longer lateral process gently curved, bearing four or more discrete denticles, separated by U-shaped spaces. Basal cavity shallow, flared beneath the cusp and tapering to a point at the tip of each process.

Sa element - trichonodelliform; bilaterally symmetrical with a recurved cusp of sub-circular cross-section. Lateral processes short, each bearing three or four discrete denticles. Basal cavity flared posteriorly beneath the cusp, tapering rapidly to a very narrow groove beneath the processes.

Sb element - asymmetrical, with closely similar denticulation to the Sa element. Cusp recurved, sub-circular in transverse section and underlain by a posteriorly flared basal cavity. Shorter lateral process on two unbroken specimens with three discrete denticles; longer process directed more sharply downwards, with four or five discrete denticles. Denticles adjacent to cusp tend to be less strongly developed than the remainder.

Sc element - ligonodiniform, with a stout, recurved cusp of subcircular cross-section. Posterior process on all specimens broken, slightly curved and bowed, with discrete, posteriorly inclined denticles, which increase in size and become more closely spaced away from the cusp. Lateral process much shorter, directed directly downwards or slightly anteriorly or posteriorly; slightly offset anteriorly from the line of the anterior margin of the cusp and bearing two or three 
stout denticles. Cavity broadest and deepest beneath the cusp. continuing as a groove under the posterior process and tapering rapidly beneath the lateral process.

Remarks. These elements resemble those combined by Cooper $(1975$, p. 997) in Oulodus sp. A, in which he included forms previously referred to Plectospathodus irregularis (Branson \& Branson) and Ligonodina kentuckyensis Branson \& Branson. However, the processes on the Sa and $\mathrm{Sb}$ elements described here are shorter than on the specimens figured by Cooper (1975, pl. 2, figs $19,21)$ and, in the absence of representatives of the $P$ elements, an identity between the two apparatuses cannot be recognised.

\title{
Oulodus? fluegeli (Walliser, 1964)
}

\author{
Plate 2, figs 6-11.
}

v 1964 Lonchodina fluegeli Walliser, p. 44, pl. 6, fig. 4; pl. 32, figs 22-24.

v 1964 Neoprioniodus planus Walliser, p. 51, pl. 4, fig. 10; pl. 6, fig. 3; pl. 29, figs 12, 13, 15.

v 1964 ?Roundya trichonodelloides Walliser, p. 72, pl. 6, fig. 2; pl. 31, figs 22-25.

1966 Lonchodina fluegeli Walliser; Spasov \& Filipović, p. 42, pl. 2, fig. 10.

? 1968 Neoprioniodus planus Walliser; Igo \& Koike, p. 12, pl. 1, figs 15, 18; pl. 3, fig. 21.

v 1972 Hibbardella? trichonodelloides (Walliser); Aldridge, p. 182, pl. 6, figs 17, 18.

v 1972 Lonchodina detorta Walliser; Aldridge, p. 190, pl. 8, fig. 6.

v 1972 Lonchodina fluegeli Walliser; Aldridge, p. 190, pl. 8, fig. 7.

v 1972 Neoprioniodus planus Walliser; Aldridge, p. 195, pl. 5, fig. 23.

p 1975 Ozarkodina plana (Walliser); Sweet \& Schönlaub, p. 52, pl. 1, figs 1, 3, 4, 6 only.

Diagnosis. All elements display characteristic compression of the cusp and denticles. $\mathrm{Pa}$ and $\mathrm{Pb}$ elements with bent and twisted process, $M$ and Sc elements with flexed and variably twisted posterior processes. Basal cavity in the form of a narrow groove in all elements.

Description. Pa element - two compressed, denticulated processes diverge from the compressed cusp. Shorter process unbroken on two specimens, on which it bears four or five discrete denticles. Longer process broken on all specimens, with the upper edge twisted away from the shorter process. Basal cavity narrow, widest beneath the cusp and continuing as a groove beneath both processes.

$\mathrm{Pb}$ element - detortiform, with two bent, compressed and denticulated processes of similar length diverging laterally from the strongly compressed, erect cusp. Denticles on both processes compressed and closely packed. Basal cavity shallow, flared beneath the cusp and tapering rapidly to a groove beneath the processes.

M element - neoprioniodontiform, with a tall, laterally compressed and posteriorly inclined cusp. Anterior edge of cusp sharp; no anterior or antero-lateral process. Posterior process compressed and flexed, bearing six to eight closely-packed denticles. Basal cavity shallow and narrow, widest below the posterior edge of the cusp.

Sa element - hibbardelliform, with a laterally compressed cusp that extends posteriorly and may develop into a denticulated posterior bar. Compressed lateral processes, of equal length, arising from the anterior edge of the cusp and directed laterally, downwards and somewhat anteriorly. Basal cavity deepest beneath the cusp, extended posteriorly as a wide groove and beneath the lateral processes as a narrow groove. 
Sb element - asymmetrical, with a laterally compressed cusp that is extended a little posteriorly at the base. Antero-lateral processes of different lengths diverging from the anterior edge of the cusp, directed downwards and bearing compressed, closely spaced denticles. Denticles on shorter process broad. Shallow basal cavity widest and deepest beneath the anterior edge of the cusp, extended as a broad groove posteriorly and as a narrow groove beneath the antero-lateral processes. Some specimens display morphological transition with the $\mathrm{Sa}$ and $\mathrm{Pb}$ elements.

Sc element - specimens that unquestionably represent this element have not been recognised. A few ligonodiniform specimens display a twisted posterior bar with a groove-like basal cavity and a lateral process arising directly from the anterior margin of the cusp and in these respects compare with the $\mathrm{Sa}$ and $\mathrm{Sb}$ elements of $O$ ? fluegeli. The denticles, however, are more widely spaced and peg-like and these specimens may belong elsewhere.

Remarks. The specimens described above are not generally well preserved and the reconstruction of $O$ ? fluegeli is based largely on material from Britain and the Carnic Alps. A sample from horizon 1OJ of Walliser (1964) at Cellon, Carnic Alps, has yielded two specimens of the Pa element, one of the $\mathrm{Pb}$, seven of the $\mathrm{M}$, six of the $\mathrm{Sa}$, three of the $\mathrm{Sb}$ and six specimens of a compressed hindeodelliform element that may represent the Sc component of this apparatus. Similar associations occur in several British collections, notably from horizons H.V.4 and Sheinton 2 (Aldridge, 1972).

The Pa element was formerly referred to Lonchodina fluegeli Walliser sensu Aldridge (1972) and the $\mathrm{Pb}$ element to Lonchodina detorta Walliser sensu Aldridge (1972). Both elements appear to be encompassed in the range of specimens referred by Walliser (1964) to L. fluegeli, the holotype being a $\mathrm{Pb}$ element. The M element is Neoprioniodus planus of Walliser (1964), which is extremely difficult to distinguish from the $\mathrm{M}$ element of Ozarkodina polinclinata (Nicoll \& Rexroad), reconstructed by Cooper (1977, p. 1058).

The reconstructed apparatus named Ozarkodina plana (Walliser) by Sweet \& Schönlaub (1975) comprises $\mathrm{Pa}, \mathrm{M}, \mathrm{Sa}$ and $\mathrm{Sb}$ elements here referred to O? fluegeli together with a spathognathodontiform (identified as Spathognathodus gulletensis Aldridge) and a hindeodelliform element (identified as Hindeodella equidentata Rhodes sensu Aldridge). The spathognathodontiform element figured by Sweet \& Schönlaub (1975, pl. 1, fig. 2) does not compare closely with British specimens referred to $S$. gulletensis, the basal angle, lateral blade thickening and denticulation indicating a stronger similarity to Spathognathodus inclinatus (Rhodes) sensu Aldridge (1972). The form species Hindeodella equidentata and Spathognathodus inclinatus have been included by several authors (Walliser, 1972; Klapper \& Murphy, 1975; Aldridge, 1975; Barrick \& Klapper, 1976) in the multielement species Ozarkodina excavata (Branson \& Mehl) [Hindeodella excavata (Branson \& Mehl) of Jeppsson, 1969]. O. excavata has not, as yet, been formally described from strata of Llandovery age, but elements that appear to represent such an apparatus occur commonly in the British Llandovery (Aldridge, 1972, tables I-IV). It appears probable that Sweet \& Schönlaub's spathognathodontiform and hindeodelliform specimens also belong to $O$. excavata or its ancestor and that their Ozarkodina plana apparatus includes elements from two unrelated taxa.

Although the elements of $O$ ? fluegeli can be confidently matched with homologous elements of other Oulodus species, they depart from the generic diagnosis given by Sweet \& Schönlaub $(1975$, p. 45$)$ in possessing denticles that are compressed and closely spaced rather than "stout, discrete, peg-like, and separated from adjacent denticles by U-shaped spaces." Hence the generic assignment is questioned. 
1933a Ozarkodina Branson \& Mehl, p. 51.

1933a Plectospathodus Branson \& Mehl, p. 47.

1933a Spathodus Branson \& Mehl, p. 46.

1941 Spathognathodus Branson \& Mehl, p. 98.

1969 Hindeodella Bassler; Jeppsson, p. 13.

1970 Ozarkodina Branson \& Mehl; Lindström, pp. 439-440.

Type species. By original designation, Ozarkodina typica Branson \& Mehl 1933a, p. 51; from the Silurian Bainbridge Formation of Missouri. Junior subjective synonym of Ozarkodina confluens (Branson \& Mehl 1933).

\section{Ozarkodina broenlundi sp. nov.}

Plate 1, figs 18-25.

Holotype. MGUH 14049, Pl. 1, fig. 19; Pa element; from GGU sample 184125, Member F, un-named Silurian limestone formation, Børglum Elv, Peary Land, eastern North Greenland.

Diagnosis. Elements $\mathrm{Pa}, \mathrm{Pb}, \mathrm{M}, \mathrm{Sa}, \mathrm{Sb}, \mathrm{Sc}$; all with shallow, restricted basal cavities. $\mathrm{Pa}$ element spathognathodontiform, with a prominent cusp and a large denticle immediately anterior to the cusp; denticles at anterior end of blade high. Pb element ozarkodiniform, with closely-packed denticles and an undulose aboral edge.

Description. Pa element - spathognathodontiform. Blade of length 0.43 to $0.77 \mathrm{~mm}$ bearing 10 to 13 denticles. Cusp prominent, laterally compressed, posteriorly inclined and situated a little posterior of the mid-point. Denticles posterior to cusp number three to five; posteriorly inclined, commonly of sub-equal size, but on four specimens one denticle is broader and higher than its neighbours. Denticles anterior to cusp number five to eight, those in central portion of anterior blade being small and closely packed. Denticle immediately anterior to cusp almost as high as the cusp, broad and posteriorly inclined. Up to three erect denticles at anterior end of blade are higher than their neighbours. Basal cavity shallow with narrow lips, elongated antero-posteriorly and widest beneath the cusp or a little to its anterior.

$\mathrm{Pb}$ element - ozarkodiniform. Cusp prominent, posteriorly inclined, laterally compressed with sharp anterior and posterior edges. Denticles number seven to nine anterior to cusp, six or seven to the posterior, closely packed and posteriorly inclined except at anterior end, where they are erect. Denticle immediately anterior to cusp higher and broader than the remainder. Anterior and posterior ends of blade slightly downturned and, together with the basal cavity lips, producing an undulose aboral edge. Basal cavity minute, widest beneath cusp and narrowing rapidly anteriorly and posteriorly.

$\mathrm{M}$ element - neoprioniodontiform. Cusp high, erect or inwardly inclined, compressed with very sharp anterior and posterior edges. Anterior process very short, directed somewhat outwards and bearing one or two small denticles. Basal cavity small and shallow, widest beneath the cusp and narrowing rapidly anteriorly and posteriorly.

Sa element - trichonodelliform, with short lateral processes, curved a little posteriorly and enclosing an angle of $65-77^{\circ}$. Cusp erect, with very sharp lateral margins. Each lateral process with four or five compressed denticles, fused for most of their height. Basal cavity small, slightly flared posteriorly beneath the cusp. 
Sb element - plectospathodontiform. Cusp inclined and slightly twisted, lenticular in transverse section, with sharp edges. Shorter process with four to eight flattened denticles, generally increasing in height away from the cusp to a large denticle that may be broader and heigher than the cusp. This denticle may be flanked at the extreme end of the process by one or two smaller denticles. Longer process flexed posteriorly and slightly twisted, bearing six to nine denticles of sub-equal size. Basal cavity minute, restricted to the aboral surface beneath the cusp.

Sc element - hindeodelliform. Cusp high, slightly inclined posteriorly, laterally compressed with sharp anterior and posterior edges. Posterior process broken on all specimens, somewhat inwardly bowed and bearing laterally compressed, posteriorly inclined denticles that increase in height and breadth away from the cusp. Anterior process more or less inwardly bowed and commonly directed rather sharply downwards to enclose an angle of $107-135^{\circ}$ with the posterior process. Denticles of anterior process discrete, four to six in number, less flattened than those of the posterior bar. Basal cavity minute, mostly without flared lips; restricted to the aboral surface beneath the cusp.

Remarks. In overall morphology the elements are closely similar to those of Ozarkodina confluens (Branson \& Mehl), the resemblance being most marked in the $\mathrm{M}$ element and the elements of the symmetry transition series. The shallow, restricted basal cavities of $O$. broenlundi elements, together with the slightly different denticulation and process orientations, serve to distinguish this species. Particularly characteristic are the two high, broad denticles at the centre of the Pa element.

\section{Ozarkodina aff. O. polinclinata Nicoll \& Rexroad, 1969}

Plate 2, figs 1-5.

aff. 1969 Spathognathodus polinclinatus Nicoll \& Rexroad, p. 60, pl. 2, figs 19, 20.

aff. 1977 Ozarkodina polinclinata (Nicoll \& Rexroad); Cooper, p. 1058, pl. 1, figs 11, 13, 14, 15, $17,18$.

Description. Pa element - spathognathodontiform, short and compact. Blade straight or slightly bowed, laterally compressed or somewhat thickened on larger specimens; bearing 11 or 12 closely-packed denticles. Highest denticles posterior of midlength, denticle height decreasing anteriorly and posteriorly. Anterior denticles erect, posterior denticles inclined posteriorly. Basal cavity shallow and narrow, widest beneath the high denticles, with the flare extending nearly to the posterior tip.

$\mathrm{Pb}$ element - ozarkodiniform, with a prominent cusp. Cusp slightly curved, posteriorly inclined, laterally compressed with sharp anterior and posterior edges. Anterior and posterior blades short with discrete, laterally compressed denticles. Anterior blade with two to four denticles of subequal size; posterior blade twisted outwards and bearing four denticles on two unbroken specimens. Basal cavity shallow, flared beneath the cusp with narrow lips extending almost to the posterior tip.

M element - neoprioniodontiform, with a tall, compressed cusp. Cusp with sharp anterior and posterior edges, inclined posteriorly and sometimes bent a little inwards. Posterior process straight or slightly flexed with five denticles on unbroken specimens; no anterior or anterolateral process. Denticles of subequal size, inclined posteriorly at an increasing angle away from the cusp. Basal cavity shallow, flared quite strongly beneath the posterior margin of the cusp and continuing as a groove beneath the posterior process. 
Sa element - trichonodelliform, with short lateral processes, enclosing an angle of about $60^{\circ}$. Cusp erect, triangular in transverse section with sharp lateral and posterior edges. Each lateral process with four to six compressed denticles, fused for much of their height. Basal cavity small, slightly flared posteriorly beneath the cusp and narrowing rapidly laterally.

Sb element - asymmetrical. Cusp subtriangular in transverse section, posteriorly inclined and slightly twisted. Shorter process with three or four discrete, subequal denticles; longer process with up to seven smaller discrete, subequal denticles. Basal cavity small, slightly elongated posteriorly.

Sc element - four fragmentary hindeodelliform specimens may represent this element. The cusp is laterally compressed and the processes are similar in attitude to those of the specimen figured by Cooper (1977, pl. 1, fig. 14).

Remarks. The Pa element in this collection is shorter than that described by Nicoll \& Rexroad (1969) and lacks the larger denticles at the anterior end. Otherwise, all elements compare closely to those included in the apparatus of $O$. polinclinata, as reconstructed by Cooper (1977).

The close similarity between the $\mathrm{M}$ element of $O$. polinclinata and that of Oulodus? fluegeli has resulted in them both being previously referred to the same form-species, Neoprioniodus planus Walliser. In the Greenland material, specimens with more widely flaring cavities have been assigned to $O$. polinclinata, but the similarity is so close that it is possible that several specimens of this element have been wrongly assigned. Similarly, the elements of the transition series in $O$. polinclinata are very similar to those of $O$. broenlundi, and broken specimens are again of uncertain assignment.

Acknowledgments. I would like to thank the Geological Survey of Greenland for making the sample available for examination and description. Dr. J.S. Peel of GGU kindly arranged the loan of the material. I also thank Mr. L. Green and Mr. D.J. Jones for photographic assistance, Mrs. J. Wilkinson for the figure and Miss J.L. Salsbury for typing the manuscript.

\section{References}

Aldridge, R.J. 1972: Llandovery conodonts from the Welsh Borderland. Bull. Br. Mus. nat. Hist. (Geol.) 22, 125-231.

Aldridge, R.J. 1975: The stratigraphic distribution of conodonts in the British Silurian. J. geol. Soc. Lond. 131, 607-618.

Barrick, J.E. \& Klapper, G. 1976: Multielement Silurian (late Llandoverian - Wenlockian) conodonts of the Clarita Formation, Arbuckle Mountains, Oklahoma, and phylogeny of Kockelella. Geol. Palaeont. 10, 59-100.

Branson, E.B. \& Mehl, M.G. 1933a: Conodonts from the Bainbridge (Silurian) of Missouri. Univ. Mo. Stud. 8, 39-53.

Branson, E.B. \& Mehl, M.G. 1933b: Conodonts from the Plattin (Middle Ordovician) of Missouri. Univ. Mo. Stud. 8, 101-119.

Branson, E.B. \& Mehl, M.G. 1941: New and little known Carboniferous conodont genera. J. Paleont. 15, 97-106.

Christie, R.L. \& Peel, J.S. 1977: Cambrian-Silurian stratigraphy of Børglum Elv, Peary Land, eastern North Greenland. Rapp. Grønlands geol. Unders. 82, $48 \mathrm{pp}$.

Cooper, B.J. 1975: Multielement conodonts from the Brassfield Limestone (Silurian) of Southern Ohio. J. Paleont. 49, 984-1006. 
Cooper, B.J. 1977: Toward a familial classification of Silurian conodonts. J. Paleont. 51, 1057-1071.

Dawes, P.R. 1976: Precambrian to Tertiary of northern Greenland. In Escher, A. \& Watt, W.S. (edit.) Geology of Greenland, 248-303. Copenhagen: Geol. Surv. Greenland.

Igo, H. \& Koike, T. 1968: Ordovician and Silurian conodonts from the Langkawi Islands, Malaya, Part 2. Geol. Palaeont. S.E. Asia 4, 1-21.

Jeppsson, L. 1969: Notes on some upper Silurian multielement conodonts. Geol. Fören. Stockh. Förh. 91, 12-24.

Jeppsson, L. 1971: Element arrangement in conodont apparatuses of Hindeodella type and in similar forms. Lethaia 4, 101-123.

Jepsen, H.F. 1971: The Precambrian, Eocambrian and early Palaeozoic stratigraphy of the Jørgen Brønlund Fjord area, Peary Land, North Greenland. Bull. Grønlands geol. Unders. 96 (also Meddr. Grønland 192,2) $42 \mathrm{pp}$.

Klapper, G. \& Murphy, M.A. 1975: Silurian - Lower Devonian conodont sequence in the Roberts Mountains Formation of central Nevada. Univ. California Pub. geol. Sci. 111, 62 pp.

Klapper, G. \& Philip, G.M. 1971: Devonian conodont apparatuses and their vicarious skeletal elements. Lethaia 4, 429-252.

Klapper, G. \& Philip, G.M. 1972: Familial Classification of reconstructed Devonian Conodont Apparatuses. Geol. Palaeont. SB-1, 97-114.

Lindström, M. 1970: A suprageneric taxonomy of the conodonts. Lethaia 3, 427-445.

Mostler, H. 1967: Conodonten aus dem tieferen Silur der Kitzbühler Alpen (Tirol). Ann. In. naturh. Mus. Wien. 71, 295-303.

Nicoll, R.S. \& Rexroad, C.B. 1969: Stratigraphy and conodont paleontology of the Salamonie Dolomite and Lee Creek Member of the Brassfield Limestone (Silurian) in south eastern Indiana and adjacent Kentucky. Indiana geol. Surv. Bull. 40, 75 pp.

Peel, J.S. \& Christie, R.L. 1975: Lower Palaeozoic stratigraphy of southern Peary Land, eastern North Greenland. Rapp. Grønlands geol. Unders. 75, 21-25.

Pollock, C.A., Rexroad, C.B. \& Nicoll, R.S. 1970: Silurian conodonts from northern Michigan and Ontario. J. Paleont. 44, 743-764.

Rexroad, C.B. 1967: Stratigraphy and conodont paleontology of the Brassfield (Silurian) in the Cincinnati Arch area. Indiana geol. Surv. Bull. 36, 64 pp.

Rexroad, C.B. \& Nicoll, R.S. 1971: Summary of Conodont Biostratigraphy of the Silurian System of North America. In Sweet, W.C. \& Bergström, S.M. (edit.) Symposium on Conodont Biostratigraphy. Mem. geol. Soc. Amer. 127, 207-225.

Rexroad, C.B. \& Nicoll, R.S. 1972: Conodonts from the Estill Shale (Silurian, Kentucky and Ohio) and their bearing on Multielement Taxonomy. Geol. Palaeont. SB-1, 57-74.

Schönlaub, H.P. 1975: Conodonten aus dem Llandovery der Westkarawanken (Österreich). Verh. Geol. B.-A. 1975, 2-3, 45-64.

Spasov, H. \& Filipović, I. 1966: Konodontska Fauna Starijeg i Mladeg Paleozoika Ji i Sz Bosne. Geol. Glasn. 11, 33-53.

Stauffer, C.R. 1930: Conodonts from the Decorah Shale. J. Paleont. 4, 121-128.

Stauffer, C.R. 1935a: Conodonts of the Glenwood Beds. Bull. geol. Soc. Amer. 46, 125-168.

Stauffer, C.R. 1935b: The conodont fauna of the Decorah Shale (Ordovician). J. Paleont. 9, 596-620.

Sweet, W.C. \& Schönlaub, H.P. 1975: Conodonts of the Genus Oulodus Branson \& Mehl, 1933. Geol. Palaeont. 9, 41-59.

Walliser, O.H. 1964: Conodonten des Silurs. Abh. hess. Landesamt. Bondenforsch. 41, 106 pp.

Walliser, O.H. 1972: Conodont apparatuses in the Silurian. Geol. Paleont. SB-1, 75-80. 


\section{Plate 1}

All illustrations are scanning electron micrographs with a magnification of $\times 54$. All specimens are from GGU sample 184125.

Figs. 1, 6, 7. Aulacognathus bullatus (Nicoll \& Rexroad). 1, upper view of Pa element MGUH 14034;6, 7, upper and lower views of $\mathrm{Pa}$ element MGUH 14035.

Figs. 2, 3. Aulacognathus sp. Lateral and upper views of Pb element, MGUH 14036.

Figs 4, 5. Aulacognathus latus (Nicoll \& Rexroad). Upper and lower views of Pa element, MGUH 14037.

Fig. 8. Carniodus sp. Inner lateral view of MGUH 14038.

Figs 9, 10. Llandoverygnathus celloni (Walliser). 9, lateral view of Pa element, MGUH 14039; 10, upper view of Pa element, MGUH 14040.

Fig. 11. Llandoverygnathus pennatus (Walliser). Upper view of Pa element, MGUH 14041.

Figs 12-15. Llandoverygnathus sp. 12, lateral view of Pb element, MGUH 14042; 13, posterior view of Sb element?, MGUH 14043; 14, outer lateral view of Sc element, MGUH 14044; 15, inner lateral view of M element, MGUH 14045.

Figs 16, 17. Distomodus staurognathoides (Walliser). 16, upper view of Pa element, MGUH 14046; 17, inner lateral view of M element, MGUH 14047.

Figs 18-25. Ozarkodina broenlundi sp. nov. 18, lateral view of Pa element, MGUH 14048; 19, lateral view of holotype, Pa element, MGUH 14049; 20, lateral view of Pb element, MGUH 14050; 21, upper view of Pa element, MGUH 14051; 22, inner lateral view of M element, MGUH 14052; 23, inner lateral view of Sc element, MGUH 14053;24, posterior view of Sa element, MGUH 14054;25, posterior view of Sb element, MGUH 14055. 


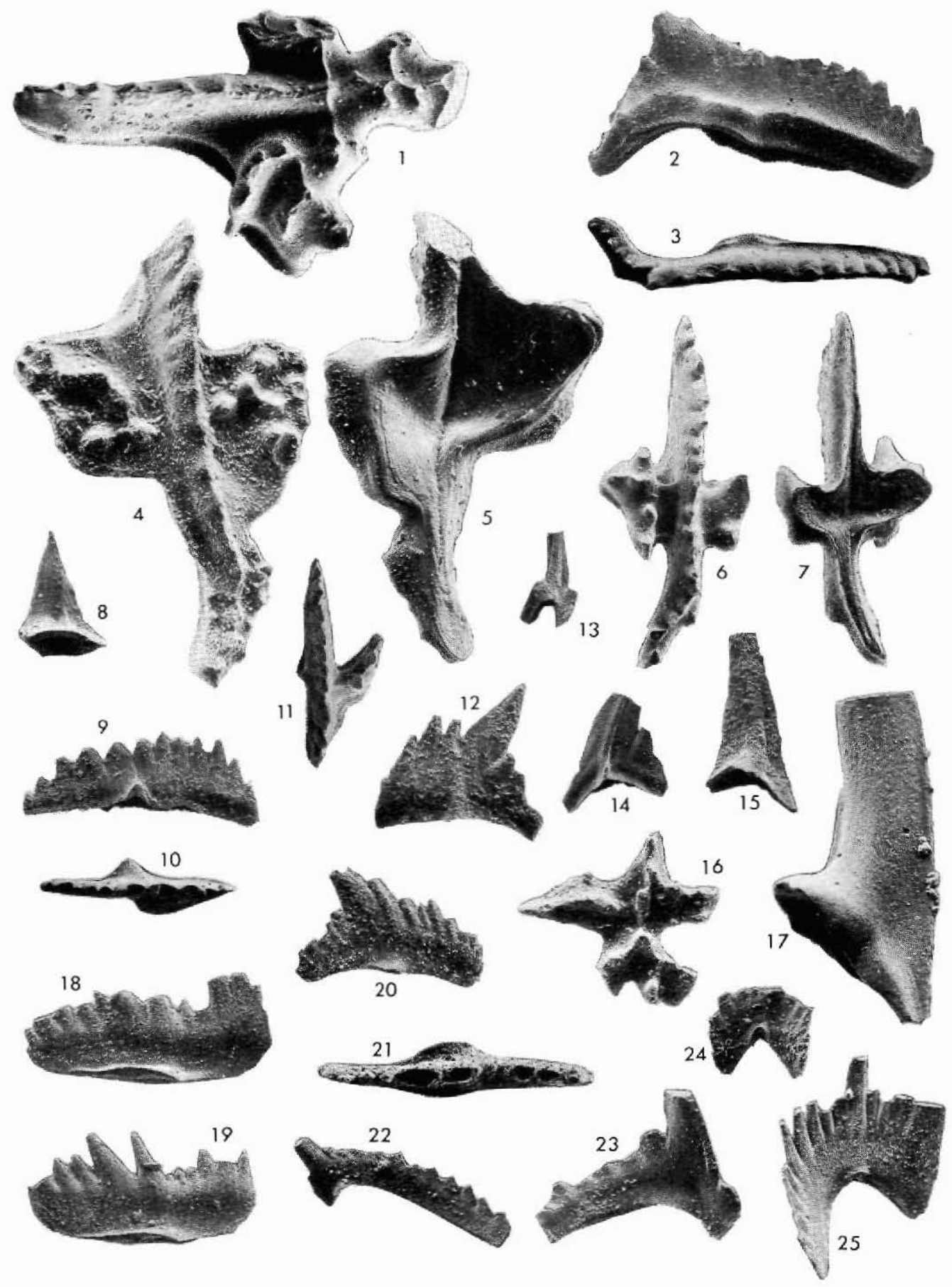




\section{Plate 2}

All illustrations are scanning electron micrographs with a magnification of $\times 54$. All specimens are from GGU sample 184125.

Figs 1-5. Ozarkodina aff. O. polinclinata (Nicoll \& Rexroad). 1, lateral view of Pa element, MGUH 14056; 2, inner lateral view of Pb element, MGUH 14057; 3, inner lateral view of M element, MGUH 14058; 4, posterior view of Sb element, MGUH 14059; 5, posterior view of Sa element, MGUH 14060.

Figs 6-11. Oulodus? fluegeli (Walliser). 6, oblique posterior view of Pa element, MGUH 14061; 7, posterior view of Pb element, MGUH 14062; 8, inner lateral view of M element, MGUH 14063; 9, posterior view of Sa element, MGUH 14064; 10, posterior view of Sb element, MGUH 14065;11, inner lateral view of Sc element?, MGUH 14066.

Fig. 12. Oulodus sp. B Cooper 1975. Inner lateral view of M element, MGUH 14067.

Figs 13-16. Oulodus sp. A. 13, inner lateral view of M element, MGUH 14068; 14, inner lateral view of Sc element, MGUH $14069 ; 15$, posterior view of Sa element, MGUH 14070;16, posterior view of $\mathrm{Sb}$ element, MGUH 14071.

Figs 17-22. Panderodus unicostatus (Branson \& Mehl). 17, 22, lateral views of simplexiform element, MGUH 14072;18, 21, lateral views of slender costate element, MGUH 14073;19, 20, lateral views of broad costate element, MGUH 14074.

Figs 23-30. Panderodus spp. 23, 28, lateral views of specimen MGUH 14075;24, 27, lateral views of specimen MGUH 14076; 25, 26, lateral views of specimen MGUH 14077; 29, 30, lateral views of specimen MGUH 14078. 


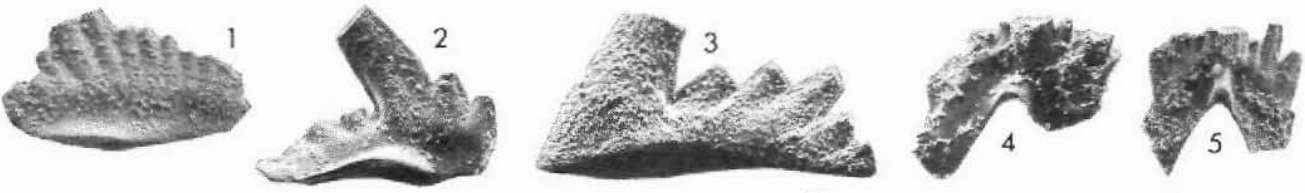
슨
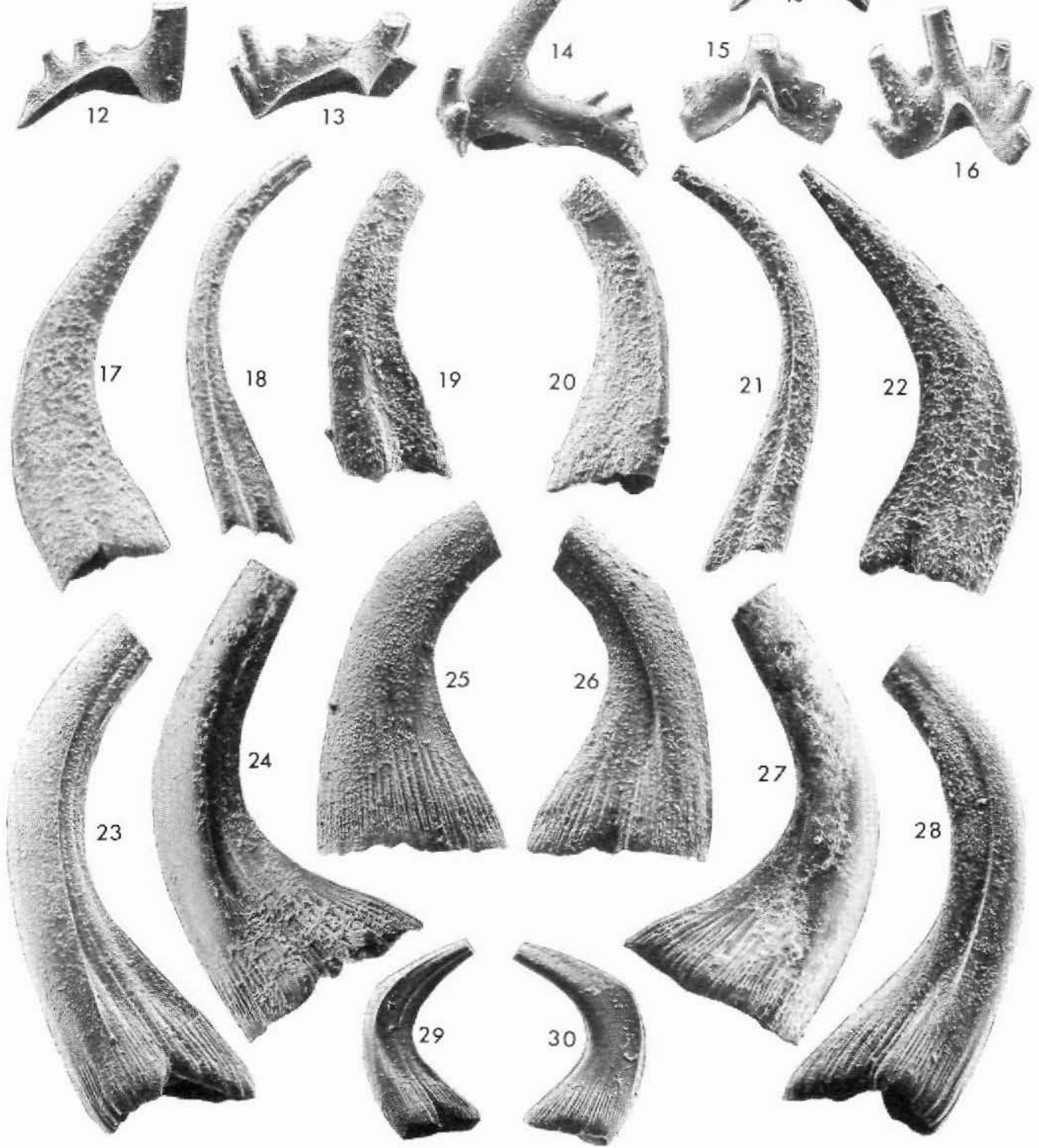